\title{
MEDIA RELATIONS WITH AN EMPHASIS ON CZECH PRACTICE
}

\author{
Miroslav Karlíček*
}

Media Relations can be perceived as the most important technique of Public Relations (PR). Research conducted by the Association of Public Relations Agencies (APRA) in 2008 proved that most major Czech companies use this tool. Based on this research, 86 percent of the participating companies communicate with the media. ${ }^{1}$

Organizations use Media Relations primarily for creating positive coverage and for offsetting negative media coverage. The media reach all of an organization's audiences and their messages are trusted because journalists are perceived as objective. Publicity can thus be very powerful. An unknown brand can become a star virtually overnight and similarly, in just a few hours, a brand can be seriously harmed or even destroyed. That is why it is crucial to understand the media properly and learn how to cooperate with them.

The goal of this study is to analyze the fundamentals of effective Media Relations in the Czech marketing context. The study focuses especially on the practical aspects of doing Media Relations in the Czech Republic. It tries to analyze the motivations and perceptions of both journalists and organizations. Based on these insights, the study attempts to draw basic guidelines for successful Media Relations.

In contrast to advertising, PR professionals do not buy media space. They supply journalists with information, which is more or less connected to their organizations or products. Journalists then use the information in their articles or reports if they find the information interesting to their readers, listeners or viewers. This means that the editorial print space or broadcast time is obtained free of charge. On the other hand, the journalist is the one who controls the content of the message. As a result, PR professionals have limited control over the final output.

The key ability of a PR professional is to produce information which, on the one hand, conveys the organization's marketing messages and, at the same time, attracts the attention of the media. Unfortunately, producing such information is usually quite difficult.

To determine which information may be interesting for the media, it is necessary first to analyze the motivations of people working in the media. The most important

\footnotetext{
* Vysoká škola ekonomická v Praze, Fakulta podnikohospodářská (karlm@vse.cz).

1 APRA press release of 10 December 2008 (provided to author by APRA).
} 
assumption for understanding the media is to accept the fact that the media are a product. Media owners get money principally from publishing companies' advertisements. Their primary interest is thus a wide readership, listenership or viewership, which is vital for attracting advertisers.

In this context, the term "infotainment" is often mentioned. It describes the tendency of the media to integrate their informing function with entertaining. This tendency is not only typical of so-called "tabloid media" but more or less of all general media. "Public service media" are an exception to some extent. These media are obliged to also inform about topics which are not covered enough by commercial media (e. g., cultural events, philanthropic activities, minorities, etc.).

The interests of media owners clearly influence journalists. They have to respect the needs of their employers and thus create stories which satisfy the readers, viewers or listeners. At the same time, journalists are expected to be objective, truthful and unbiased. They must never take part in publishing hidden advertising. ${ }^{2}$ Last but not least, journalists usually have a lot of work, have to respect strict deadlines and often have to work on topics they do not know much about.

The work of a journalist can be quite demanding. Journalists therefore appreciate help. If a trustworthy source produces a story which is interesting for their target audience, makes it balanced, puts it in the correct form and sends it to the journalist before his or her deadline, the journalist will accept the story with gratitude.

\section{Figure 1}

\section{The Czech Media Scene}
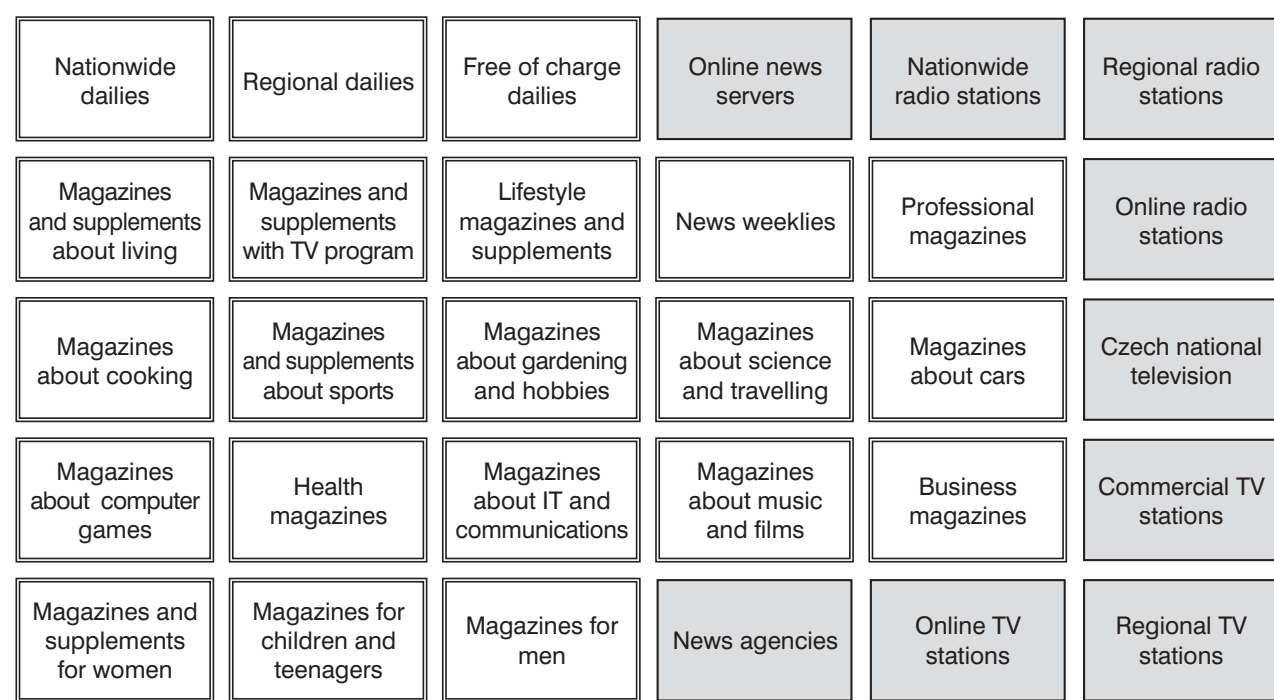
stations
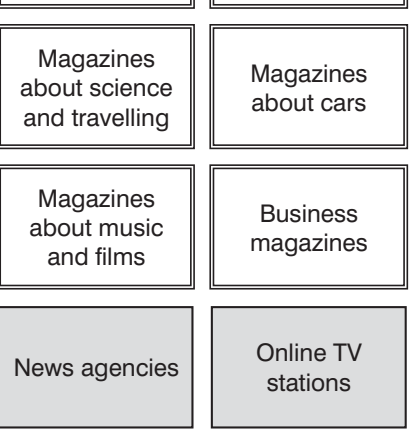

Online radio stations

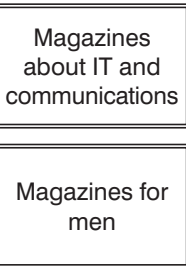

Magazines out music and films

Source: the author.

2 See the Code of Journalism Ethics. 
The demands of journalists vary according to the medium they work for. These demands on both content and form correspond to the role of the particular medium on the media scene. Figure 1 shows a simplified scheme of the Czech media scene. It should be clear from this figure that the variety of the media is large and cannot be ignored.

The media do not only differ in their focus on entertaining (general versus public service media). They also vary in their orientation towards local or nationwide topics (regional versus nationwide media). Some media are much more focused on specific audiences (e. g., women) or specific topics (e. g., business) too.

However, there is also a significant difference in the time focus of each medium. Journalists from dailies, TV stations, news internet servers and radio stations inform primarily about current news. Day-old information is usually unusable to them. These journalists therefore need information very quickly. Journalists from weekly and monthly media are less time-pressed. Their approach is usually more analytical and in-depth. For monthlies, there is a large gap between issue preparation and publishing. Information sent to these media is thus published with a significant delay.

After this brief description of the motivations of the media, the motivations of organizations should be analyzed. Professionals responsible for Media Relations are often responsible to supervisors who often do not have sufficient knowledge and experience with the media. The main motivation of these supervisors is often to "sell" their brand. What they actually expect is advertising texts about their brand published in the media for free.

Of course, these expectations are not realistic. Organization-focused information is mostly perceived by journalists as biased and trivial and gets little or no attention. Such information conflicts with the principle of refusing hidden advertising. It would also not be welcomed by the readers, viewers and listeners as most people do not prefer to read commercial and partial information.

Supervisors are then unhappy that their texts do not get published. However, even when the texts do get published they are usually different from what they approved. Such experience often moves supervisors away from using Media Relations. An important part of PR professionals' work is therefore educating their supervisors about media.

The Czech "news markets" is very competitive nowadays. Based on a 2003 research study, each Czech journalist was emailed 46 press releases on average weekly. ${ }^{3}$ This number can be expected to have grown, though, as more and more Czech organizations actively cooperate with the media.

Most of the press releases are deleted because they are not good enough in both content and form. Unusable sources of information include especially those that are self-promoting, biased and trivial, and those that are filled with superlatives, have poor style, grammar mistakes or are simply too long.

Based on the 2003 research study, Czech journalists claimed that half of all the press releases did not contain any newsworthy information. They also claimed that almost 60 percent of the press releases contained superlatives and unusable quotations.

3 Donath-Burson-Marsteller, 2003. 
Finally, they stated that almost half of the press releases were badly written, too long and often without clearly formulated statements. ${ }^{4}$

Similar conclusions were stated in a 2008 study. ${ }^{5}$ Czech journalists and senior PR professionals were asked to summarize the most common mistakes made by Czech organizations in communication with the media. Based on this study, Czech organizations often publish press releases without any relevant or interesting information, press releases that are too extensive, and overuse superlatives and "marketing language".

A press release that has a chance to be used first of all has to be newsworthy. Many "boring commercial" press releases can be cleverly turned into more attractive forms. Generally, most attention-grabbing pieces are of course scandals, disasters and sensations. However, using these topics is usually not the best way for organizations to create publicity. It is much more convenient to use, for example, stories, novelties, trends, comparisons, and practical advice. In general, media appreciate information that brings practical advice and is entertaining to wide audiences. Regional media disseminate practical and entertaining information to local audiences. Specialized media concentrate on their specific audiences.

Sometimes it is even better to communicate information which is not related to the organization. The organization may, for example, offer expert comments on interesting happenings in society. Such comments can be very useful to journalists while helping the organization build its reputation.

The relationship between PR practitioners and journalists is a partnership, even though sometimes it may look different. PR professionals need journalists to gain publicity for their organizations and journalists need PR professionals as important sources of information for their editorials. For example, it was estimated that almost 60 percent of media content in Germany and 80 percent of media content in the USA came from PR. ${ }^{6}$

However, there are some abrasive surfaces in this partnership. These conflicts stem chiefly from the different motivations of both groups. Journalists can sometimes be bothered when PR executives urge journalists to publish self-promoting articles about their organizations and products. Such undue pressure can be even connected with an effort to indebt the journalist (with gifts, artificial friendships, etc.). Logically, this is perceived by journalists as restraining their freedom and can seriously harm the mutually rewarding relationship.

An even more serious mistake is when a PR executive tries to manipulate the information. Manipulation is perceived highly negatively by journalists. A misused journalist will never trust the manipulator again. Manipulating should therefore be avoided.

Journalists can also be angry at being "spammed" by unusable press releases and being interrupted by annoying phone calls. Communication with a journalist should therefore be considerate.

\footnotetext{
4 Ibid.

5 Unpublished internal study by Ogilvy Public Relations Prague (provided to author by Ogilvy Public Relations Prague)

6 Svoboda, V, 2006.
} 
On the other hand, PR professionals sometimes perceive journalists as incompetent and irresponsible people who make mistakes all the time and never fulfill anything they promised. This perception could partly explain the pushy approach of some PR professionals who try to control journalists' work. It is important to understand, though, that journalists' "mistakes" and "irresponsibility" derive mostly from the nature of the journalists' job. Sometimes they are even a result of journalists' superiors' actions. For example, editors sometimes change articles to make them more "appealing" or even substitute an article with another one.

Journalists can also sometimes be denunciated for being mere story- and scandalseekers who ignore facts that are in dissonance with what they plan to write. Sometimes they can be criticized for immorality as well. Of course, each journalist is different but it is possible to encounter even such negative experiences. These would be exceptions that require individual solutions.

Ethical standards for Media Relations are set out in the Charter on Media Transparency, which was adopted by ICCO, the international umbrella organization for PR consultancies. ${ }^{7}$ Consistent with the Code of Journalism Ethics, this charter states that an "editorial" is a result of the judgment of a journalist and must not be a result of any payment or barter by any third party. An editorial which is a result of payment must be clearly identified as advertising or "advertorial". This means that not only is both direct and indirect bribing of journalists unethical, but also any advertisers' influence on news content is immoral.

In an ideal world, there should therefore be an unbridgeable gap between the sales and editorial departments of a medium. The former should focus on attracting advertisers and the latter should produce objective news. There should also be a clear demarcation line between media and PR departments on the advertiser's side. The former should buy media space and the latter should do Media Relations. Unfortunately, in reality temptation exists on both sides of the game.

The media have an ambiguous role. Their mission is to inform objectively but, at the same time, they need money from advertising in a highly competitive environment. Advertisers want publicity. In this constellation, the possibility of some unethical behavior will always exist.

Of course, the extent of unethical behavior differs from market to market. Research done with 219 advertising directors of US daily newspapers reflects the approach to unethical practices in the USA. ${ }^{8}$ According to the research, smaller dailies that have less financial stability are especially vulnerable.

A similar tendency is to be expected on the Czech market. The majority of Czech media distinguish editorial and advertorial texts properly. However, smaller peripheral media sometimes offer free editorial space in exchange for advertising.

Most ethically fraught are situations where an advertiser threatens more or less directly to withdraw its spending if the medium publishes unfavorable coverage. The

7 International Communications Consultancy Organisation.

8 An, S., Bergen, L., 2007. 
advertiser thus tries to "kill a negative story". Such behavior is difficult to prove but is widely believed to exist on the Czech news market.

It is important to note, though, that unethical behavior can seriously damage a company's reputation in the eyes of both the general public and journalists. It is often ineffective, too. For example, it is more effective to create a good story which will get appropriate attention than to try to pay for a hidden advertisement in a peripheral medium. By doing that, media can even serve as a lens which helps to make the message more attractive to readers, viewers or listeners.

Press releases and press conferences are the most important tools in Media Relations. Both of these tools should be used only in situations where the organization has something newsworthy to communicate. This is especially important for press conferences. If a journalist does not get information he or she expects, he or she may not come the next time.

A press release should have a standard form which respects the needs of journalists. First of all, it should be short - no more than one or two pages. Other in-depth information can be attached as a supplement. Longer press releases can be perceived by journalists as too complex or unprofessional and therefore, ignored.

A press release should focus on one topic only. There should be a simple and clear headline in a press release, possibly also a sub-headline. The headline should be followed by a paragraph which summarizes all of the most important facts. These facts should give answers to the questions "who, when, where, why, and how". The headline and the first paragraph are crucial parts of any press release. Based on 2003 research, only one third of Czech journalists read more than the headline and the first paragraph to determine whether a press release was usable. ${ }^{9}$

The further text of a press release should offer more detailed information. Quotations from the organization's management and third parties can be added. The style of the press release should be simple and factual. There should be no difficult loanwords, superlatives and grammar mistakes. Shorter sentences are preferable. A press release has to contain the date and place of publishing and a contact for further information.

Organizing a press conference involves many important decisions. Those are notably which media should be invited, who is going to speak, and where and when the press conference will take place. The relevant journalists should be invited one or two weeks in advance. Approximately two days before the conference, they should be reminded because they quite often forget.

The speakers' contributions should not be altogether longer than thirty minutes and should be followed by a discussion. Altogether, a press conference should not exceed one hour. The organizers are expected to prepare high-quality press materials. In addition to a press release and its supplements, the materials may include printable pictures and videos on a $\mathrm{CD}$, brochures and other helpful information. ${ }^{10}$ It is also very

9 Donath-Burson-Marsteller, 2003.

10 The set of press materials is described as a "press pack" or a "press kit". 
important to consider other important practical decisions like refreshment, audiovisual equipment, navigation, etc.

An effective way to gain positive publicity is organizing media-attracting events. For example, Panasonic wanted to promote its Panasonic Oxyride batteries and differentiate them from other batteries on a highly competitive market. In 2006, the company carried out a unique project in Japan. It undertook the world's first flight of a manned aircraft powered just by disposable batteries. The event attracted the attention not only of the Japanese media but also media worldwide. The attentiongrabbing project achieved massive media coverage. Brand recognition increased by 30 percent and reached 85 percent. $^{11}$

Many examples of media-attracting events can be found in the Czech environment, too. For example, in 2008, mBank situated a cage with a live banker in a shopping mall and added a message "Do not feed your banker". Using this attention-grabbing approach, the bank communicated its crucial benefit - no banking fees.

Another effective way of creating positive publicity is by cooperation with opinion formers. ${ }^{12}$ Those are respected or popular authorities such as experts, celebrities, and also bloggers nowadays. These people influence others directly but, more importantly, via the media. Educating or persuading an opinion former can lead to a situation where he or she supports a brand or a project. He or she thus becomes a so-called "ambassador" for the brand or project. Another possibility is to profile a new opinion former from the pool of an organization's own experts. As mentioned, the media appreciate expert comments and interviews and the organization can provide its expertise.

In the above text, the focus has been on a proactive approach to Media Relations. In reality, however, much of Media Relations consists in reactive activities. These daily activities are usually called press service or a press center. The journalists call to ask about an organization's operations, new products, market statistics, business trends, price comparisons, etc., which they need for their editorials. In theory, a PR team has to be available 24 hours a day to answer the questions. Often the team requires information from other departments. Because the response is usually needed quickly, PR professionals have to educate their colleagues to react flexibly and quickly. It is also very important to have an online version of the press center where journalists can find all press releases, photographs, contacts and other important information.

\section{Conclusion}

Media Relations are still the most important activity in PR and their position in the marketing communication of most organizations is irreplaceable. However, many Czech companies fail to use this technique effectively. This situation is founded in the principal difference between motivations and perceptions of the media and the organizations.

11 Ads of the World, 2008.

12 Opinion formers are sometimes described as "key opinion leaders". 
Organizations supply the media with information. However, only some pieces of information receive adequate publicity. PR practitioners have to understand how to present information to journalists. They have to consider differences among particular media on the media scene and the needs of journalists. Without this know-how, Media Relations cannot be successful because news markets are very competitive nowadays.

The relationship between PR practitioners and journalists is a partnership. Each group needs the other. However, due to the different perspectives of both groups, this relationship sometimes becomes troublesome. Journalists can be irritated by undue pressure and manipulation by PR practitioners. On the other hand, PR practitioners sometimes perceive journalists as incompetent and irresponsible.

These conflicts also have an ethical dimension. Ethical standards for Media Relations are set out in the Charter of Media Transparency. The charter is consistent with the Code of Journalism Ethics. Both standards are necessary because temptation exists in Media Relations on the part of both the organizations and the media. The difference between these standards and reality is one of the most important issues of Media Relations.

Press releases and press conferences are the most important tools in Media Relations. Another important tool for generating publicity is based on holding mediaattracting events. Cooperation with opinion formers can sometimes be effective too. Last but not least, reactive activities connected with the press service are among the most important tools in Media Relations.

\section{References}

ADLER, R. B.; ELMHORST, J. M. 2002. Communicating at Work: Principles and Practices for Business and the Professions. 7th ed. Boston : McGraw-Hill, 2002.

Ads of the World. 2008. [on-line]. [2008-10-15]. Available at http://adsoftheworld.com/media/ambient/ matsushita_oxyride_batteries_manned_airplane_project?size=_original.

AN, S.; BERGEN, L. 2007. Advertiser Pressure on Daily Newspapers: A Survey of Advertising Sales Executives. Journal of Advertising. 2007, vol. 36, no. 2, s. 111-121.

BOVÉE, C. L.; THILL, J. V. 1992. Marketing. New York : McGraw-Hill, 1992.

BUDIŠ, P.; ŠTĚDROŇ, B. 2009. Sichere elektronische Kommunikation. 1st ed. Chemnitz : GUC, 2009. ISBN 978-3-934235-77-9.

DeFlEUR, M. L.; BALLOVÁ-ROKEACHOVÁ, S. J. 1996. Teorie masové komunikace. 1st ed. Praha : Karolinum, 1996.

Donath-Burson-Marsteller. 2003. Czech Journalists Survey. [on-line]. 2003 [2008-10-23]. Available at www.dbm.cz/pruzkumy/?id=74.

Donath-Burson-Marsteller. 2003. Slovak Journalists Survey. [on-line]. 2003 [2008-10-25]. Available at www.dbm.cz/pruzkumy/?id=74.

DRU, J. M. 2002. Beyond Disruption: changing the rules in the marketplace. New York : John Wiley \& Sons, Inc., 2002.

EXNER, L.; RAITER, T.; STEJSKALOVÁ, D. 2005. Strategický marketing zdravotnických zařizení. 1st ed. Praha : Professional Publishing, 2005.

FILL, C. 2005. Marketing Communications: engagement, strategies and practice. 4th ed. Prentice Hall Europe, 2005.

FORET, M. 2003. Marketingová komunikace. 1. vyd. Brno : Computer Press, 2003.

FREY, P. 2005. Marketingová komunikace: nové trendy a jejich využití. 1st ed. Praha : Management Press, 2005

HAWKINS, D. I.; BEST, R. J.; CONEY, K. A. 1995. Consumer Behavior. 6th ed. Chicago : Irwin, 1995. 
APRA Press release of 10 December 2008 (provided to author by APRA).

Unpublished internal study of Ogilvy Public Relations Prague from 2008 (provided to author by Ogilvy Public Relations Prague).

International Communications Consultancy Organization. Media Transparency Charter. [on-line]. 2005 [2008-10-05]. Available at http://www.iccopr.com/images/documents/media\%2520 transparency\%2520charter.pdf.

LEHMANN, D. R.; WINTER, R. S. 2005. Analysis for Marketing Planning. 6th ed. New York : McGraw-Hill/ Irwin, 2005.

MACHKOVÁ, H. 2006. Mezinárodní marketing. 2nd ed. Praha : Grada Publishing, 2006.

MACHKOVÁ, H; MALÝ, J.; ŠTĚRBOVÁ, L. 2002. Marketing a mezinárodní podnikání (vybrané problémy). Praha : VŠE FMV KMO, 2002.

ROBINSON, E. J. 1966. Communication and Public Relations. Columbus : Charles E. Merrill Books, 1966.

ROSSITER, J. R.; BELLMAN, S. 2005. Marketing Communications: theory and applications. Pearson Education Australia, 2005.

ŠÁLEK, M; FEŘTEK, T. 2001. Novináři nejsou zlí: mediální rukověť pro neziskové organizace. Praha : Nadace Via, 2001.

SCOTT, D. M. 2006. The New Rules of PR. [on-line]. 2006. [2008-08-18]. Available at http://www. davidmeermanscott.com/documents/New_Rules_of_PR.pdf.

SHIMP, T. A. 1993. Promotion Management \& Marketing Communications. $3^{\text {rd }}$ ed. The Dryden Press, 1993.

SUTHERLAND, M.; SYLVESTER, A. K. 2000. Advertising and the Mind of the Consumer. $2^{\text {nd }}$ ed. London : Kogan Page Limited, 2000.

SVOBODA, V. 2006. Public relations: moderně a účinně. 1st ed. Praha : Grada Publishing, 2006.

Syndikát novinářů České republiky. 1998. Etický kodex novináře. [on-line]. 1998 [2008-10-05]. Available at http://www.syndikat-novinaru.cz/index.php?web=1\&main $=5 \&$ sub $=36 \&$ main_tit $=$ Etika \&sub_tit=Eticky_kodex.

TELLIS, G. J. 2004. Effective Advertising: Understanding When, How, and Why Advertising Works. Sage Publications, 2004.

WHITE, J.; MAZUR, L. 1995. Strategic Communications Management: making public relations work. Addison-Wesley Publishers, 1995.

ZAMAZALOVÁ, M. 2008. Business Marketing management in the Czech republic. Linz 06.11.2008. In FH Science Day. Aachen : Shaker Verlag, 2008, s. 244-252. ISBN 978-3-8322-7643-0.

\section{MEDIA RELATIONS WITH AN EMPHASIS ON CZECH PRACTICE}

Abstract: The study analyzes the fundamentals of effective Media Relations. The emphasis is on the specifics of the Czech environment. The study attempts to analyze the perspective of journalists and the corresponding perspective of organizations. Based on these assumptions, concrete guidelines for successful Media Relations are drawn. Due to the high competition on the current Czech "news market", information from most organizations typically attracts little attention from the media or even no attention at all. However, the relationship between public relations practitioners and journalists is a partnership. When an organization respects the perspective of the media, it can achieve large positive publicity. Public relations practitioners therefore have to adjust their activities and behavior to the motivations and perceptions of journalists.

Keywords: Media Relations, publicity, public relations, Czech media scene, Charter on Media Transparency

\section{JEL Classification: M 39}

